\title{
Equivalence of Mycobactins from Mycobacterium senegalense, Mycobacterium farcinogenes and Mycobacterium fortuitum
}

\author{
By RICHARD M. HALL* AND COLIN RATLEDGE \\ Department of Biochemistry, University of Hull, Hull HU6 $7 R X, U K$
}

(Received 31 December 1984; revised 24 February 1985)

\begin{abstract}
Mycobactins were isolated from five strains designated Mycobacterium farcinogenes and a similar number designated Mycobacterium senegalense following growth under conditions of iron-limitation. These lipid-soluble iron-chelating compounds were characterized by a combination of thin-layer and high-performance liquid chromatography. The mycobactins from both the slow-growing $M$. farcinogenes and the rapidly-growing $M$. senegalense strains proved impossible to differentiate both from each other and from those produced by strains of Mycobacterium fortuitum, indicating a close relationship between all three species. However, Nocardia farcinica, previously implicated with the bovine farcy strains, produced a different mycobactin which was easily distinguished by thin-layer chromatography alone.
\end{abstract}

\section{INTRODUCTION}

The classification and identification of those actinomycetes causing bovine farcy, a serious disease of Zebu cattle in Africa (Mostafa, 1966; Chamoiseau, 1969, 1972) has proved to be a complex taxonomic problem which still requires some clarification. Lipid analysis (Chamoiseau \& Asselineau, 1970) showed that mycolic acids typical of the genus Mycobacterium were produced by these organisms and later serological studies by Ridell (1975) confirmed this view. This evidence was perhaps surprising since the causal agent of bovine farcy had long been considered to be Nocardia farcinica, at that time the type strain of the genus Nocardia (Nocard, 1888; Trevisan, 1889). Chamoiseau (1973) proposed the name Mycobacterium farcinogenes for the farcy strains and recognized two subspecies, tchadense and senegalense. However, differences in growth rate, DNA homology, chemical activity and pathogenicity later allowed these subspecies to be given full species status as Mycobacterium farcinogenes and Mycobacterium senegalense (Chamoiseau, 1979). Recent serological and chemical studies have questioned this division and also demonstrated a close relationship of the designated species with Mycobacterium fortuitum (Ridell, 1981, 1983; Ridell et al., 1982; Ridell \& Goodfellow, 1983; Minnikin \& Goodfellow, 1980).

In this study we have compared the mycobactins produced by representative strains of $M$. farcinogenes, $M$. senegalense, $M$. fortuitum and $N$. farcinica in order to clarify the relationships between these taxa. Mycobactins, which are lipid-soluble iron-chelating compounds characteristic of the genera Mycobacterium and Nocardia, have recently been confirmed as excellent chemotaxonomic markers for Mycobacterium and related taxa based on their species-specificity and highly conserved nature (Hall \& Ratledge, 1984).

\section{METHODS}

Strains. The sources of the test strains are given in Table 1

Growth and maintenance. Strains were maintained on glucose/yeast extract/agar slopes (Gordon \& Mihm, 1962) or as dense suspensions of cells frozen in $20 \%(\mathrm{v} / \mathrm{v})$ glycerol at $-20{ }^{\circ} \mathrm{C}$ (Wellington \& Williams, 1978). To encourage formation of mycobactin organisms were grown on either glycerol/asparagine/agar or glucose/yeast extract/agar as previously described (Hall \& Ratledge, 1982). 
Table 1. Organisms grown under conditions of iron-limitation for mycobactin production

Lab.

no. ${ }^{*}$

M725

N719

N710

M269

N711

N718

N723

N728

N721

M263

M368

M369
Designation and source

\author{
M. farcinogenes, M. Ridell, N73; M. Magnusson, Statens Seruminstitut, Copenhagen, Denmark, \\ 749; bovine farcy, Farcha Laboratory, Fort Lamy, Chad. \\ M. farcinogenes, M. Ridell, BF12; M. P. Lechevalier, Rutgers University, New Brunswick, NJ, \\ USA, 1225; bovine farcy, Farcha Laboratory, Fort Lamy, Chad. \\ M. farcinogenes, M. Ridell, BF2, University of Gothenburg, Sweden; R. E. Gordon, Rutgers \\ University, New Brunswick, NJ, USA, 1226; bovine farcy, Farcha Laboratory, Fort Lamy, Chad. \\ M. farcinogenes.

* Laboratory numbers correspond to the collection of Dr M. Goodfellow, Department of Microbiology, University of Newcastle upon Tyne, UK. Full details of strain histories not given here appear in Ridell \& Goodfellow (1983). NCTC, National Collection of Type Cultures, London, UK.

$\dagger$ Type strain.

Isolation and characterization of mycobactins. Bacteria were harvested, mycobactins isolated and their yields determined after partial purification as previously described (Hall \& Ratledge, 1982, 1984). Mycobactins were analysed by thin-layer chromatography (TLC), in a single dimension, using various adsorbents and solvents: system I, silica gel G, $20 \mathrm{~cm} \times 20 \mathrm{~cm}$ (Analtech, Newark, USA) developed with petroleum spirit (b.p. $60-80^{\circ} \mathrm{C}$ )/ ethyl acetate/n-butanol $(2: 3: 3$, by vol.); system II (Merck, product no. 11844), silica gel $60,10 \mathrm{~cm} \times 20 \mathrm{~cm}$ with a $2.5 \mathrm{~cm} \times 10 \mathrm{~cm}$ concentrating zone, developed with petroleum spirit/ethyl acetate $/ n$-butanol $(2: 3: 3$, by vol.); system III (Merck, product no. 13748), high performance thin-layer plates, $10 \mathrm{~cm} \times 10 \mathrm{~cm}$, including a $2.5 \mathrm{~cm} \times$ $10 \mathrm{~cm}$ concentrating zone (BDH), developed with petroleum spirit/ethyl acetate $/ n$-butanol $(2: 3: 3$, by vol.); system IV, alumina GF, $20 \mathrm{~cm} \times 20 \mathrm{~cm}$ (Analtech), developed with cyclohexane $/ n$-butanol $(9: 1, \mathrm{v} / \mathrm{v}) ;$ system V, plates as for system I but using methanol/ethyl acetate $(4: 1, \mathrm{v} / \mathrm{v})$ for development; system VI, plates as for system I but using propan-1-ol as solvent (Hall \& Ratledge, 1984).

HPLC analyses of the mycobactins were done with a Spectra-Physics (Santa Clara, Calif., USA) SP 8000 instrument. A solvent gradient, changing over $30 \mathrm{~min}$ from methanol/water $(80: 20, \mathrm{v} / \mathrm{v})$ to methanol alone, was used with a flow rate of $2 \mathrm{ml} \mathrm{min}^{-1}$ and a column temperature of $50{ }^{\circ} \mathrm{C}$. A Lichrosorb RP18 reverse-phase column $(4 \mathrm{~mm} \times 250 \mathrm{~mm})$ (Jones Chromatography, Llanbradach, Mid-Glamorgan, UK) was used as previously described (Hall \& Ratledge, 1984) with the eluate monitored at $450 \mathrm{~nm}$ using a UV-visible detector (SpectraPhysics model 770). All solvents were of HPLC grade quality. The relative percentages of the various peaks were calculated by the electronic integrator of the instrument.

\title{
RESULTS AND DISCUSSION
}

Mycobactins were isolated from all of the test strains (Table 1) following their growth under conditions of iron-limitation on solid medium (Hall \& Ratiedge, 1982). These compounds were then characterized by both TLC and HPLC, an approach which has been shown to be a powerful technique for resolving mycobactins from various mycobacteria (Hall \& Ratledge, 1984).

Analysis by single-dimensional TLC (Table 2) showed that mycobactins isolated from $M$. farcinogenes, $M$. senegalense and $M$. fortuitum could not be differentiated by any of the six TLC systems used. As shown previously (Hall \& Ratledge, 1984), multiple strains of the same species produced mycobactins with identical TLC migration values, again highlighting the intraspecies consistency of these molecules. The mycobactin isolated from $N$. farcinica was however distinct and could be readily differentiated from those of the other species examined by any of the TLC systems except system IV. This distinction of $N$. farcinica from $M$. farcinogenes and $M$. senegalense confirms earlier work which used lipid and immunological analyses (Ridell et al., 1982). In addition, the mycobactin produced by $N$. farcinica also allows its differentiation from other Nocardia species (R. M. Hall \& C. Ratledge, unpublished results). 
Table 2. Thin-layer chromatography of mycobactins isolated from test strains

The $R_{F}$ values obtained from TLC with different solvent systems are given.

$\begin{array}{ccccccc}\text { Test strain } & \overbrace{\text { I }} & \text { II } & \text { III } & \text { IV } & \text { V } & \text { VI } \\ \text { M. farcinogenes M269† } & 0.46 & \frac{0.34}{0.31} & \frac{0.41}{0.40} & 0.34 & 0.87 & 0.51 \\ \text { N. farcinica ATCC 3318 } & 0.31 & 0.20 & 0.18 & \text { St } & 0.67 & 0.33\end{array}$

$* \frac{x}{y}$ refers to a double spot with both $R_{F}$ values given; St, streak.

$\dagger$ Mycobactins from all other strains of $M$. farcinogenes, $M$. senegalense and $M$. fortuitum co-chromatographed with that from $M$. farcinogenes M269.

Table 3. Yields of mycobactins and their analysis by HPLC

A Lichrosorb RP18 reverse-phase column was used with a solvent gradient changing from methanol/water $(80: 20, \mathrm{v} / \mathrm{v})$ over $30 \mathrm{~min}$ to methanol alone. Only peak areas $>2 \%$ of the final chromatogram are shown.

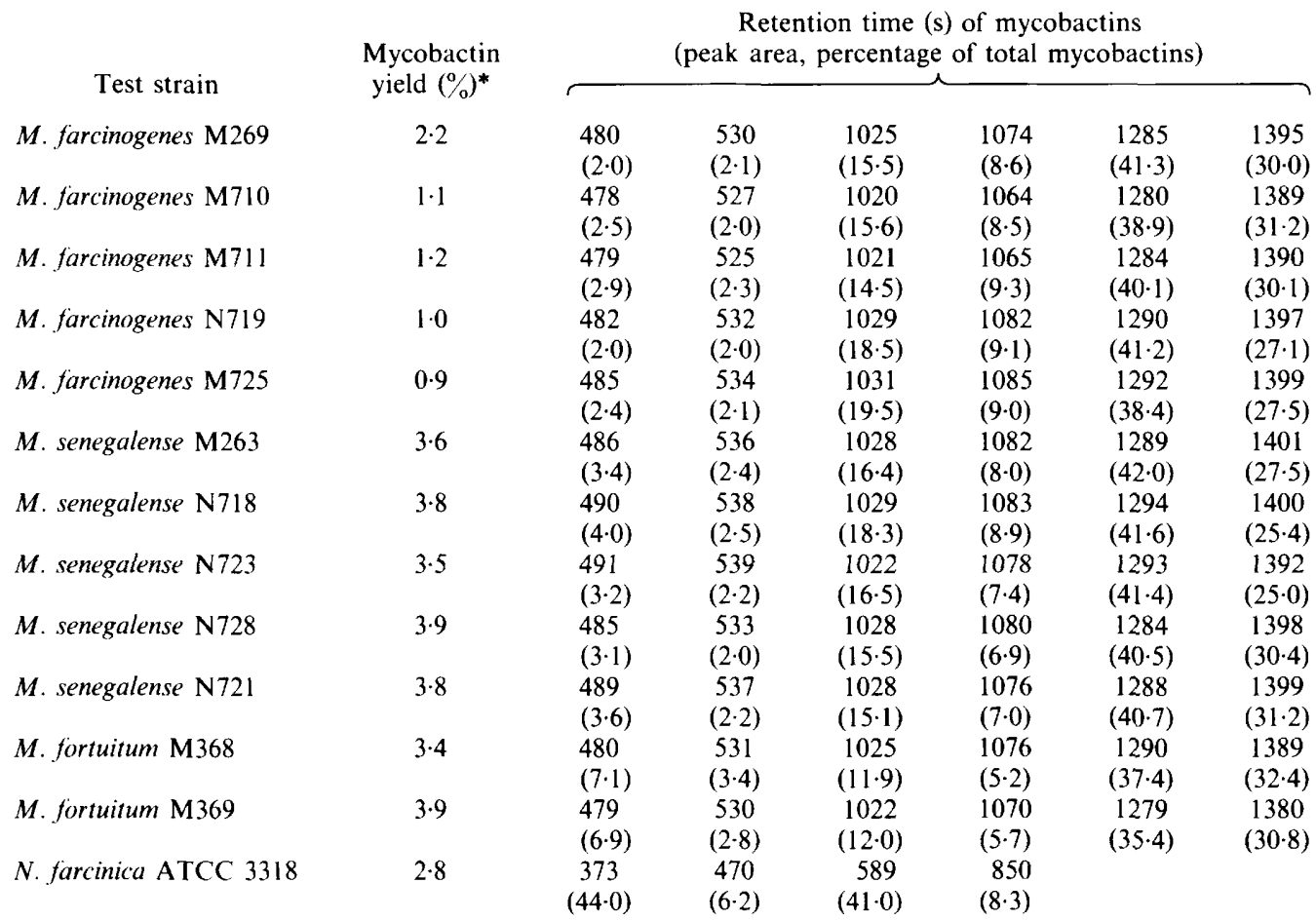

* Expressed as percentage of cell dry weight.

Isolated mycobactins were then examined by reverse-phase HPLC, which resolves an individual mycobactin into a number of components according to the length of the major alkyl chain substituent (Ratledge \& Ewing, 1978). A 'finger print' for each mycobactin is provided which allows accurate identification of the producing organism (Hall \& Ratledge, 1984). As before, the mycobactins from $M$. farcinogenes, $M$. senegalense and $M$. fortuitum, which could not be differentiated by TLC, were indistinguishable from each other (Fig. 1, Table 3). Previously, 

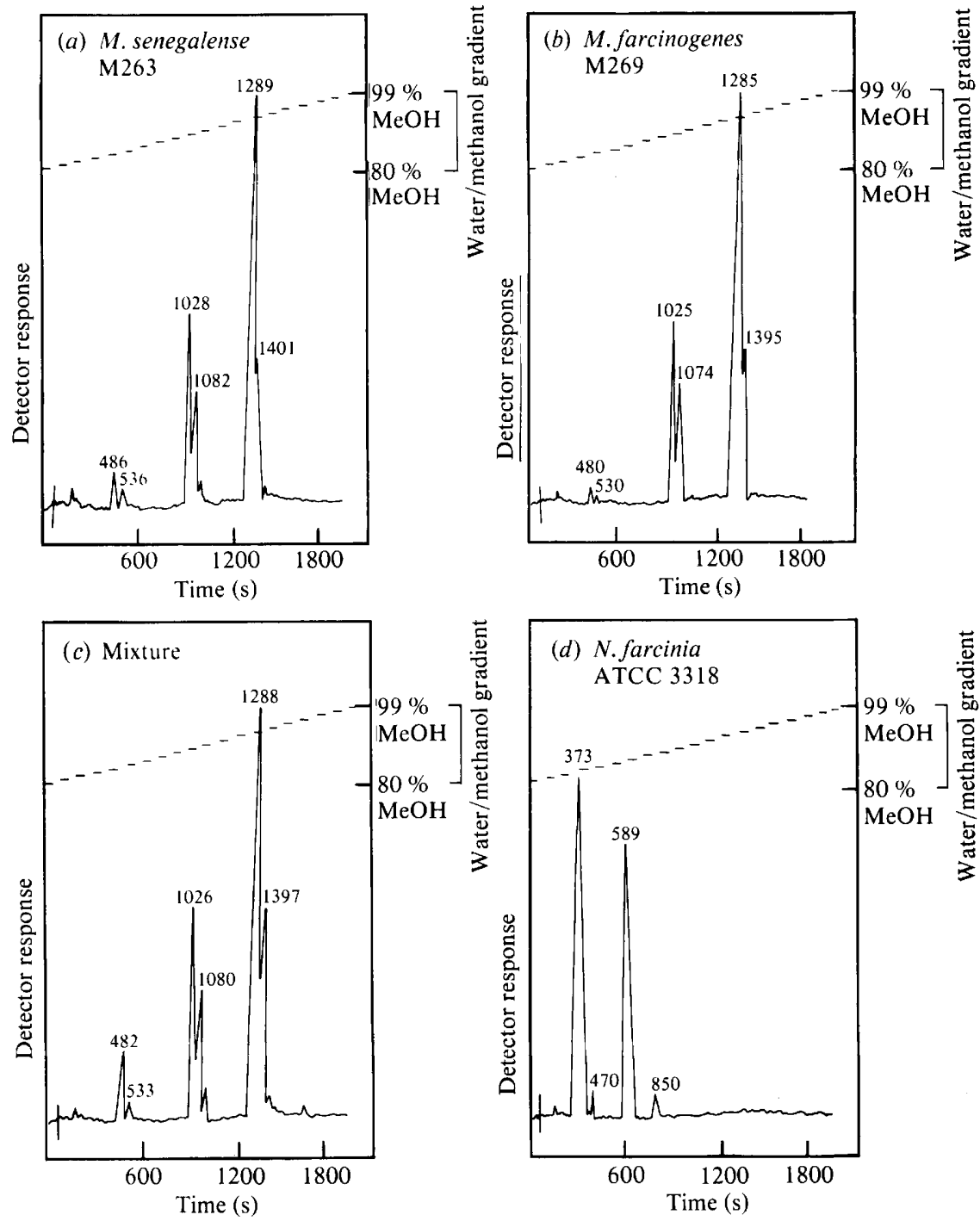

Fig. 1. HPLC of mycobactins isolated from (a) M. senegalense M263, (b) M. farcinogenes M269, (c) a mixture of mycobactins from $M$. senegalense M263, $M$. farcinogenes $\mathrm{M} 269$ and $M$. fortuitum NCTC 10394 and $(d) N$. farcinica A TCC 3318. The mycobactins were separated using a reverse-phase column $(250 \mathrm{~mm} \times 4 \mathrm{~mm}$ Lichrosorb RP18) with a solvent gradient changing from methanol/water $(80: 20$, $\mathrm{v} / \mathrm{v}$ ) to methanol alone over $30 \mathrm{~min}$. A flow rate of $2 \mathrm{ml} \mathrm{min}^{-1}$ and a column temperature of $50{ }^{\circ} \mathrm{C}$ were maintained throughout. Peaks are labelled with retention times in seconds; quantitative data are given in Table 3.

$M$. fortuitum strains has been shown to give a three doublet 'finger print' with reverse-phase HPLC (Hall \& Ratledge, 1984) and this was confirmed. Although there were some minor differences in the relative proportions of some of the peaks (Table 3 ), these were negligible compared to the overall similarity of the mycobactins. When mycobactin samples isolated from these three species were mixed and re-examined by HPLC, the same three doublet pattern was still seen, thereby confirming that the mycobactins were identical (Fig. 1c). Thus on the basis of their mycobactins the three species $M$. farcinogenes, $M$. senegalense and $M$. fortuitum are judged to be equivalent. HPLC examination of the mycobactin synthesized by $N$. farcinica again confirmed its dissimilarity from the remaining test strains (Fig. 1d). The yields of the 
mycobactins (Table 3) from representatives of $M$. farcinogenes are generally lower than those from strains of $M$. senegalense and $M$. fortuitum, perhaps reflecting the higher growth rate of the latter two species.

The results of this work confirm and extend the conclusions from previous work using lipid and serological analysis. On the basis of lipid analysis (Ridell et al., 1982), $M$. farcinogenes and $M$. senegalense could not be differentiated; each contained $\alpha$-mycolates and characteristic polar mycolates, derived from epoxymycolic acids, a pattern also found in $M$. smegmatis, $M$. fortuitum and 'Mycobacterium peregrinum' (Minnikin et al., 1984). Mycolic acid TLC patterns may not be sensitive enough to permit species definition however (Minnikin \& Goodfellow, 1980). Serological analysis also indicates that $M$. farcinogenes and $M$. senegalense are closely related to each other and to $M$. fortuitum and to a lesser extent to $M$. phlei and $M$. smegmatis (Ridell et al., 1979, 1982).

The mycobactins synthesized by $M$. fortuitum, $M$. phlei and $M$. smegmatis have previously been shown to be clearly different and characteristic of three distinct taxa (Hall \& Ratledge, 1984). In contrast, the mycobactins isolated from $M$. fortuitum, $M$. farcinogenes and $M$. senegalense are indistinguishable using the present TLC and HPLC systems. Recent numerical studies (Ridell \& Goodfellow, 1983) have shown that $M$. senegalense has a high overall similarity with $M$. fortuitum while the slower-growing $M$. farcinogenes cluster appeared to be distinct and deserving full species status. Preliminary DNA homology data (Baess, 1982) support the recognition of three distinct taxa corresponding to $M$. farcinogenes, $M$. fortuitum and $M$. senegalense. In view of the previously established strong correlation between the mycobactinbased chemotaxa and species level within the genus (Hall \& Ratledge, 1984; Snow, 1970), the present evidence provides no support for the separation of $M$. farcinogenes, $M$. senegalense and $M$. fortuitum into distinct species. Further detailed comparisons of the interrelationships between these three taxa should be made to determine the true significance of the present results.

We thank Mrs Janet Stephenson for assistance with media preparation and Dr M. Goodfellow who kindly provided all the mycobacterial strains. R. M.H. gratefully acknowledges the support of a grant from the Medical Research Council.

\section{REFERENCES}

BAESS, I. (1982). Deoxyribonucleic acid relatedness among species of rapidly-growing mycobacteria. Acta pathologica et microbiologica Scandinavica Section B 90, 371-375

Chamoiseau, G. (1969). De l'étiologie du farcin de zébus tchadiens: nocardiose ou mycobactériose? I. Etude bacteriologique et biochimique. Revue d'élevage et de médecine veterinaire des pays tropicaux $\mathbf{2 2}$, 195-204.

Chamoiseau, G. (1972). De l'étiologie du farcin de zébus tchadiens: nocardiose ou mycobactériose? III. Activité amidasique. Revue d'élevage et de médecine veterinaire des pays tropicaux 25, 191-194.

Chamoiseau, G. (1973). Mycobacterium farcinogenes, agent causal du farcin du boeuf en Afrique. Annales de Microbiologie 124A, 215-222.

Chamoiseau, G. (1979). Etiology of farcy in African bovines: nomenclature of the causal organisms Mycobacterium farcinogenes Chamoiseau and $\mathrm{Myco-}$ bacterium senegalense (Chamoiseau) comb. nov. International Journal of Systematic Bacteriology 29, 407-410.

Chamoiseau, G. \& Asselineau, J. (1970). Examen des lipides d'une souche de Nocardia farcinica: présence d'acides mycoliques. Comptes rendus hebdomadaire des séances de l'Académie des sciences 270D, 26032604.

GORDON, R. E. \& MiHM, J. M. (1962). Identification of Nocardia caviae (Erikson) nov. comb. Annals of the New York Academy of Sciences 98, 628-636.

HaLL, R. M. \& RatLedGe, C. (1982). A simple method for the production of mycobactin, the lipid-soluble siderophore, from mycobacteria. FEMS Microbiology Letters 15, 133-136.

Hall, R. M. \& Ratledge, C. (1984). Mycobactins as chemotaxonomic characters for some rapidly growing mycobacteria. Journal of General Microbiology 130, 1883-1892.

Minnikin, D. E. \& Goodfellow, M. (1980). Lipid composition in the classification and identification of acid-fast bacteria. In Microbiological Classification and Identification, pp. 189-256. Edited by $\mathbf{M}$. Goodfellow \& R. G. Board. London: Academic Press.

Minnikin, D. E., Minnikin, S. M., Hutchinson, I. G., Goodfellow, M. \& Grange, J. M. (1984). Mycolic acid patterns of representative strains of Mycobacterium fortuitum, 'Mycobacterium peregrinum' and Mycobacterium smegmatis. Journal of General Microbiology 130, 363-367. 
Mostafa, I. E. (1966). Bovine nocardiosis. A review. Veterinary Bulletin 36, 189 193.

NoCARD, M. E. (1888). Note sur le maladie des boeufs de la Guadeloupe, connue sous le nom de farcin. Annales de l'Institut Pasteur 2, 291-302.

Ratledge, C. \& Ewing, D. F. (1978). The separation of the mycobactins from Mycobacterium smegmatis by using high-pressure liquid chromatography. Biochemical Journal 175, 853-857.

RIDELl, M. (1975). Taxonomic study of Nocardia farcinica using serological and physiological characters. International Journal of Systematic Bacteriology 25, 124-132.

RIDELL, M. (1981). Immunodiffusion studies of $\mathrm{MyCO}$ bacterium, Nocardia and Rhodococcus for taxonomic purposes. Zentralblatt für Bakteriologie, Parasitenkunde, Infektionskrankheiten und Hygiene (Abteilung I, Supplement II), 235-24l.

RIDELL, M. (1983). Immunodiffusion analyses of Mycobacterium farcinogenes, Mycobacterium senegalense and some other mycobacteria. Journal of General Microbiology' 129, 6!3-619.

Ridell, M. \& GoOdFellow, M. (1983). Numerical classification of Mycobacterium farcinogenes, Mycobacterium senegalense and related taxa. Journal of General Microbiology 129, 599-611.

RIDELl, M., BAKER, R., LIND, A.\& OUCHTERLONY, Ö. (1979). Immunodiffusion studies of ribosomes in classification of mycobacteria and related taxa. International Archives of Allergy and Applied Immuno$\log y$ 59, 162-172.

Ridell, M., Goodfellow, M., Minnikin, D. E., Minnikin, S. M. \& Hutchinson, I. G. (1982). Classification of Mycobacterium farcinogenes and Mycobacterium senegalense by immunodiffusion and thin-layer chromatography of long-chain components. Journal of General Microbiolog.' 128, 12991307.

SNow, G. A. (1970). Mycobactins: iron-chelating growth factors from mycobacteria. Bacteriological Revien's 34, 99- 125.

Trevisan, V. (1889). 'Generie le specie dell Bacteriacee'. Milano: Zanaboni \& Gabuzzi.

Wellington, E. M. H. \& Williams, S. T. (1978). Preservation of actinomycete inoculum in frozen glycerol. Microbios Letters 6, 151-157. 